\title{
Responses in gross primary production of Stipa krylovii and Allium polyrhizum to a temporal rainfall in a temperate grassland of Inner Mongolia, China
}

\author{
HU Xiaoxing ${ }^{1}$, Mitsuru HIROTA ${ }^{2}$, Wuyunna $^{3}$, Kiyokazu KAWADA ${ }^{2}$, LI Hao ${ }^{1}$, MENG \\ Shikang ${ }^{1}$, Kenji TAMURA ${ }^{2}$, Takashi KAMIJO ${ }^{1 *}$ \\ ${ }^{1}$ Graduate School of Life and Environmental Sciences, University of Tsukuba, Tsukuba 305-8572, Japan; \\ ${ }^{2}$ Faculty of Life and Environmental Sciences, University of Tsukuba, Tsukuba 305-8572, Japan; \\ ${ }^{3}$ College of Environment and Resources, Dalian Minzu University, Dalian 116600, China
}

\begin{abstract}
In the arid and semi-arid areas of China, rainfall and drought affect the growth and photosynthetic activities of plants. Gross primary productivity (GPP) is one of the most important indices that measure the photosynthetic ability of plants. This paper focused on the GPP of two representative grassland species (Stipa krylovii Roshev. and Allium polyrhizum Turcz. ex Regel) to demonstrate the effect of a temporal rainfall on the two species. Our research was conducted in a temperate grassland in New Barag Right Banner, Hulun Buir City, Inner Mongolia Autonomous Region of China, in a dry year 2015. We measured net ecosystem productivity (NEP) and ecosystem respiration flux (ER) using a transparent chamber system and monitored the photosynthetically active radiation (PAR), air and soil temperature and humidity simultaneously. Based on the measured values of NEP and ER, we calculated the GPP of the two species before and after the rainfall. The saturated GPP per aboveground biomass $\left(\mathrm{GPP}_{\mathrm{AGB}}\right)$ of $A$. polyrbizum remarkably increased from $0.033( \pm 0.018)$ to 0.185 $( \pm 0.055) \mu \mathrm{mol} \mathrm{CO}_{2} /(\mathrm{gdw} \cdot \mathrm{s})$ by 5.6-fold and that of $S$. krylovii decreased from $0.068( \pm 0.021)$ to 0.034 $( \pm 0.011) \mu \mathrm{mol} \mathrm{CO} /(\mathrm{gdw} \cdot \mathrm{s})$ by 0.5 -fold on the $1^{\text {st }}$ and $2^{\text {nd }} \mathrm{d}$ after a $9.1 \mathrm{~mm}$ rainfall event compared to the values before the rainfall at low temperatures below $35^{\circ} \mathrm{C}$. However, on the $1^{\text {st }}$ and $2^{\text {nd }} \mathrm{d}$ after the rainfall, both of the saturated $\mathrm{GPP}_{\mathrm{AGB}}$ values of $S$. krylovii and $A$. polyrbizum were significantly lower at high temperatures above $35^{\circ} \mathrm{C}\left(0.018( \pm 0.007)\right.$ and $0.110( \pm 0.061) \mu \mathrm{mol} \mathrm{CO}_{2} /(\mathrm{gdw} \cdot \mathrm{s})$, respectively) than at low temperatures below $35^{\circ} \mathrm{C}(0.034( \pm 0.011)$ and $0.185( \pm 0.055) \mu \mathrm{mol} \mathrm{CO} /(\mathrm{gdw} \cdot \mathrm{s})$, respectively). The results showed that the GPP responses to the temporal rainfall differed between $S$. krylovii and A. polyrbizum and strongly negative influenced by temperature. The temporal rainfall seems to be more effective on the GPP of $A$. polyrhizum than $S$. krylovii. These differences might be related to the different physiological and structural features, the coexistence of the species and their species-specific survival strategies.
\end{abstract}

Keywords: temperate grassland; gross primary productivity; temporal rainfall; survival strategy; dry year; drought

Citation: HU Xiaoxing, Mitsuru HIROTA, Wuyunna, Kiyokazu KAWADA, LI Hao, MENG Shikang, Kenji TAMURA, Takashi KAMIJO. 2019. Responses in gross primary production of Stipa krylovii and Allium polyrhizum to a temporal rainfall in a temperate grassland of Inner Mongolia, China. Journal of Arid Land, 11(6): 824-836. https://doi.org/10.1007/ s40333-019-0127-1

\footnotetext{
*Corresponding author: Takashi KAMIJO (E-mail: kamijo.takashi.fw@u.tsukuba.ac.jp)

Received 2018-05-22; revised 2018-08-06; accepted 2018-08-16

(C) Xinjiang Institute of Ecology and Geography, Chinese Academy of Sciences, Science Press and Springer-Verlag GmbH Germany, part of Springer Nature 2019
} 


\section{Introduction}

Grassland is one of the most extensive types of vegetation in the world (Adams et al., 1990). The importance of grassland ecosystems to the global carbon balance (Hunt et al., 2004; Novick et al., 2004, Xu and Baldocchi, 2004) and livestock development (Reynolds et al., 2005) is increasingly recognized. China has vast areas of grasslands, and Inner Mongolia Autonomous Region is the primary distribution area of temperate grasslands in China. Grasslands in arid and semi-arid areas are ecologically vulnerable and sensitive to climate change and human disturbances (Gao and Reynolds, 2003; Li et al., 2005), particularly to changes in rainfall (Sala et al., 1988; Knapp and Smith, 2001; Ma et al., 2007; Guo et al., 2012). In recent years, as a result of human disturbance and drought induced by climate change, the area of degraded grasslands has been increasing in Inner Mongolia (Kawada et al., 2011; Wang et al., 2015; Han et al., 2018).

Photosynthetic activity is the foundation for growth, biomass production and carbon accumulation of plants. Drought is one of the primary causes of inter-annual variation in the carbon balance because of the large decreases in gross primary productivity (GPP) and ecosystem respiration in terrestrial ecosystems (Ciais et al., 2005; Pereira et al., 2006; Granier et al., 2007; Shi et al., 2014). Plant growth strategies should be regulated primarily by rainfall in arid and semi-arid grasslands. Because the response of a community is the mixture of the responses of individual species, examining the responses of individual species is essential to understand the response of the community (Robertson et al., 2009). Li et al. (2014) determined the productivity response of Leymus chinensis, a dominant perennial grass in semi-arid grasslands in Inner Mongolia, to different rainfall regimes. Additionally, Sun and Du (2017) explored the effect of climate on net primary productivity (NPP) and precipitation use efficiency (PUE; the ratio of aboveground productivity to precipitation) and reported that with increasing precipitation. NPP increased whereas PUE decreased. However, most of the previous studies were based on annual productivity, which can only reflect all the rainfall events over the entire year (Hooper et al., 1999; Harpole et al., 2007), however, the patterns of rainfall events may change greatly in a specific year. Guo et al. (2016) reported that $\mathrm{N}$ enrichment significantly increased the total GPP in response to a temporal rainfall event in a grassland of Inner Mongolia. Their study shows that the productivity also responds to temporal rainfall events (Guo et al., 2016). Thus, to more accurately predict the influence of rainfall on productivity, it is necessary to understand how productivity responds to temporal rainfall events. Additionally, understanding the influence of rainfall regimes on different types of species is also necessary.

Several studies examine the responses of different species to changes in rainfall (Robertson et al., 2009; Liu et al., 2012), soil water content (Zhang et al., 2009; Sun et al., 2011), water depth (Hirota et al., 2006) or drought (Chen et al., 2013). Sun et al. (2011) examined photosynthesis, water use efficiency (WUE) and light use efficiency (LUE) of Stipa krylovii and Agropyron cristatum in a typical steppe of Inner Mongolia. They reported that WUE and LUE of $A$. cristatum were correlated with photosynthetically active radiation (PAR), whereas those of $S$. krylovii were not, and no obvious effect of soil water content (SWC) on the stomatal conductance of A. cristatum and S. krylovii was detected. Liu et al. (2012) demonstrated that two species (Leymus chinensis and Stipa grandis) in the grasslands of Inner Mongolia had different responses in biomass to changes in rainfall. As shown in the study of Chen et al. (2013), the responses of growth to drought stress were significantly different between $S$. grandis and $S$. krylovii in the grasslands of Inner Mongolia. Some similar studies have also been conducted for different species in other regions. In an alpine grassland on the Qinghai-Tibetan Plateau, Zhang et al. (2009) demonstrated differences in net ecosystem productivity (NEP) among three species and revealed the underlying mechanism, that is, the aboveground biomass (AGB) and SWC might contribute to the differences among the three species. In the same region, Hirota et al. (2006) compared four wetland species and found that water depth in the wetland was the major environmental driver of seasonal variation in NEP. Robertson et al. (2009) reported three dominant species with different functional traits in response to the variations in the annual amount and patterns of rainfall in a grassland of North America. Specifically, Dasylirion leiophyllum, a $\mathrm{C}_{3}$ shrub species, responded 
to frequent and large precipitation events, whereas Bouteloua curtipendula, a $\mathrm{C}_{4}$ grass species, was correlated with frequent and small summer rainfall events during short inter-pulse periods, and Opuntia phaeacantha, a crassulacean acid metabolism succulent species, was responsive to small winter and fall rainfall events with short inter-pulse periods.

Many ecological studies have been conducted with S. krylovii (Zhao et al., 2006; Chen et al., 2013; Cheng et al., 2013) and Allium polyrhizum (Ivanov et al., 2004; Cheng et al., 2013), which are two widely distributed dominant perennial $\mathrm{C}_{3}$ species in the grasslands of Inner Mongolia (Cheng et al., 2013). The $S$. krylovii community is one of the major grassland community types in the moderate temperate zone of Central Asia and is distributed over a large area, forming important pasture in Inner Mongolia. According to Zhao et al. (2006), S. krylovii is a perennial tussock grass that is rich in nutrients and palatable for livestock. Chen et al. (2013) reported that $S$. krylovii utilizes a tolerance strategy for drought stress. Although A. polyrhizum is also a perennial tussock grass, the $A$. polyrhizum community is considered to be a degraded grassland type, and it has an expectation that $A$. polyrhizum will increase as grassland deteriorates (Cheng et al., 2013). For physiological features, Ivanov et al. (2004) characterized A. polyrhizum by the high photosynthetic rate under conditions of sufficient water supply. Therefore, the two species are of considerable ecological importance and apparently have comparable physiological features relating to drought and rainfall regime.

Clarifying the eco-physiological features of $S$. krylovii and A. polyrhizum will provide comprehensive understanding of the response of the ecosystem to climate change in the grasslands of Inner Mongolia. In this study, we focused on the responses of the two species to a temporal rainfall, particularly as measured by GPP, which is essential to plant physiology and carbon balance. Our primary aims were (1) to demonstrate the relationships between GPP and environmental conditions (temperature and PAR) for the two species; (2) to determine the effect of a temporal rainfall event on the GPP of the two species in a dry year; and (3) to ascertain which species is more sensitive to the temporal rainfall.

\section{Materials and methods}

\subsection{Study area}

The study area $\left(48^{\circ} 32^{\prime} \mathrm{N}, 117^{\circ} 00^{\prime} \mathrm{E} ; 500-650 \mathrm{~m}\right.$ a.s.l.) is located in New Barag Right Banner, Hulun Buir City, Inner Mongolia Autonomous Region, China. It is a livestock industry area of Inner Mongolia. The grassland of the study area is classified as a typical temperate grassland and is dominated by S. krylovii (Wuyunna et al., 2009; Cheng et al., 2013). The annual mean temperature and mean annual precipitation during $1958-2014$ were $1.7^{\circ} \mathrm{C}$ and $242.0 \mathrm{~mm}$, respectively. Precipitation during 2011-2016 was not distributed evenly over the growing season and was concentrated in June, July and August (weather data of the Grassland Service Station in New Barag Right Banner). Our field investigation was conducted in 2015. The annual

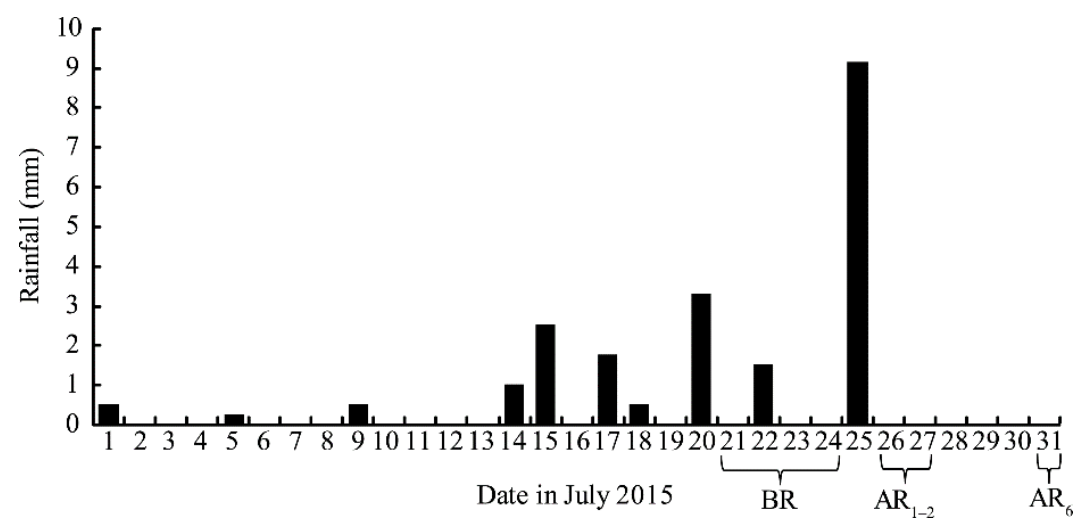

Fig. 1 Rainfall in July 2015. BR, before the rainfall; $\mathrm{AR}_{1-2}$, on the $1^{\text {st }}$ and $2^{\text {nd }} \mathrm{d}$ after the rainfall; $\mathrm{AR}_{6}$, on the $6^{\text {th }}$ $\mathrm{d}$ after the rainfall. 
precipitation in $2015(143.2 \mathrm{~mm})$ was the lowest among recent years (precipitation of $340.8 \mathrm{~mm}$ in 2013 and of $324.1 \mathrm{~mm}$ in 2014). Figure 1 shows the rainfall distribution in July 2015. The soil type in our study area was chestnut soil, and the soil hardness, organic matter content and total nitrogen in the $0-10 \mathrm{~cm}$ soil layer were $14.10( \pm 0.46) \mathrm{mm}, 2.7 \%( \pm 0.1 \%)$ and $3.90( \pm 0.28) \mathrm{g} / \mathrm{kg}$, respectively (Lin et al., 2013).

\section{2 $\mathrm{CO}_{2}$ flux and parameter measurements}

$\mathrm{CO}_{2}$ fluxes of $S$. krylovii and A. polyrhizum were measured by a static chamber system (Hirota et al., 2010) on 21-24 July and on 26, 27 and 31 July, 2015. Illustration of the growth of S. krylovii and A. polyrhizum in the study area is shown in Figure 2. The static chamber system (Fig. 3) consisted of a chamber made of transparent polyvinyl chloride (PVC), a data acquisition unit, a mini-fan for mixing air inside the chamber and a power supply (Zhang et al., 2009). The transparent chamber was a cylinder $40 \mathrm{~cm}$ in height and $25 \mathrm{~cm}$ in diameter. The size of the chamber was sufficient to enclose one individual of $S$. krylovii or A. polyrhizum in natural conditions without changing the leaf angle and without including other adjacent plants. All measurements using the chamber were conducted with individuals that represented the size of mature individuals in the study area. Vegetation properties, such as biomass and species composition, were relatively stable within the measurement period. Twenty-four hours before the measurements, 10 PVC collars $(25 \mathrm{~cm}$ diameter $\times 7 \mathrm{~cm}$ height) were installed into the soil to a depth of $5 \mathrm{~cm}$.

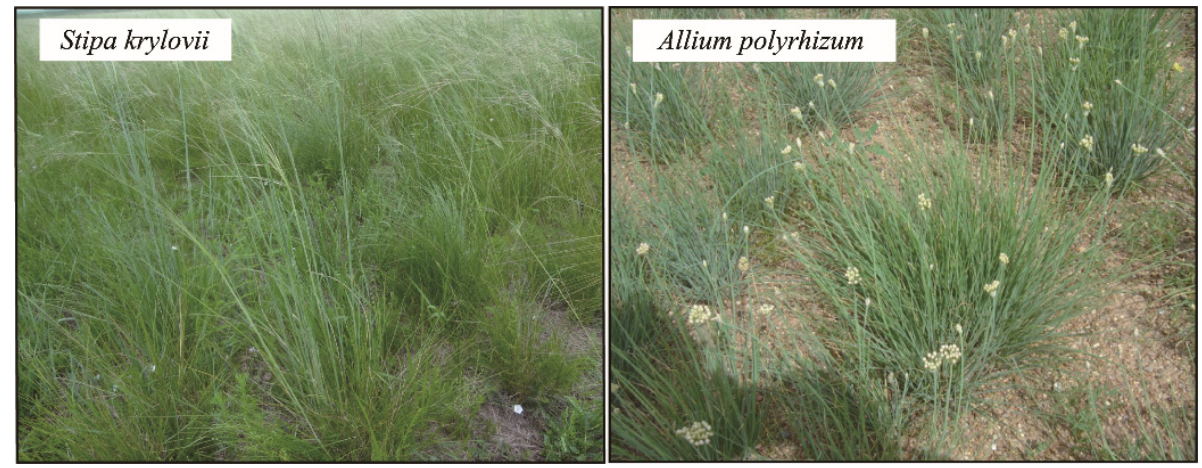

Fig. 2 Illustration of the growth of Stipa krylovii and Allium polyrhizum in the study area. Photographs were taken by HU Xiaoxing.

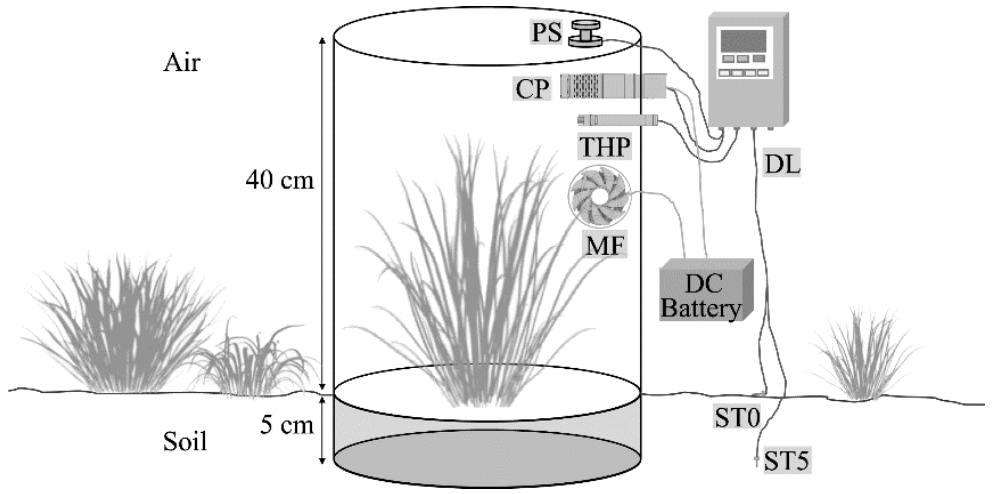

Fig. 3 The static chamber $\mathrm{CO}_{2}$ flux (net ecosystem productivity (NEP)) measurement system. MF, micro fan; PS, photosynthetically active radiation (PAR) sensor; $\mathrm{CP}, \mathrm{CO}_{2}$ probe; THP, temperature/humidity probe; DL, data logger; ST0, soil temperature at the 0-cm depth; ST5, soil temperature at the 5-cm depth.

In this study, we measured NEP and environmental parameters (air temperature and humidity inside the chamber; soil surface temperature; soil temperature at the 5-cm depth; PAR and rainfall amount) on 21-24 July and on 26, 27 and 31 July, 2015, particularly immediately before and after 
the rainfall event, using a removable acrylic transparent chamber equipped (Fig. 3) with a $\mathrm{CO}_{2}$ probe (GMP343, Vaisala, Helsinki, Finland), a very small PAR sensor (MIJ-14PAR Type2/K2, Environmental Measurement Japan Co. Ltd., Fukuoka, Japan) and an air temperature/humidity probe (MOODLE 2119A, Etodenki Co. Ltd., Tokyo, Japan). All the data were recorded every $5 \mathrm{~s}$ during 180-s period using a data logger (Thermic 2300A, Etodenki Co. Ltd., Tokyo, Japan). We corrected the PAR value based on the transparency of the chamber $(70.3 \%)$ for analysis. It should be noted that an estimate of ER is required to obtain GPP in the daytime. Additionally, the estimate is required of the light-response characteristics of photosynthesis at the whole plant level. Therefore, immediately after the NEP measurement under $100 \%$ light, we measured ER under $0 \%$ light using an opaque cloth over the chamber and then under $65 \%$ light using a shade screen and under 39\% light using a doubled shade screen.

We monitored rainfall data obtained from the weather station (WatchDog 2900ET weather station, Spectrum, Illinois, USA) near the study area and detected an extensive temporal rainfall event on 25 July. The amount of the temporal rainfall was $9.1 \mathrm{~mm}$ (1-d rainfall amount on July $25)$, which was over $40 \%$ of the total amount of rainfall $(21.1 \mathrm{~mm})$ in July. We measured NEP with the environmental parameters before the rainfall (BR; 21-24 July), on the $1^{\text {st }}$ and $2^{\text {nd }} \mathrm{d}$ after the rainfall $\left(\mathrm{AR}_{1-2} ; 26-27 \mathrm{July}\right)$ and on the $6^{\text {th }} \mathrm{d}$ after the rainfall $\left(\mathrm{AR}_{6} ; 31 \mathrm{July}\right)$. We measured NEP each day under the four light intensity levels $(0 \%, 39 \%, 65 \%$ and $100 \%)$ from full light intensity with no screen and to $0 \%$ light using an opaque shade screen. With the $\mathrm{CO}_{2}$ flux measurement, we recorded soil surface temperature and soil temperature at the 5-cm depth using thermocouples. According to the data of $\mathrm{CO}_{2}$ concentration in the chamber, NEP, ER and GPP were calculated (see Section 2.4 Data processing). For the calculation of GPP, the data of NEP and ER were collected from the same individual of S. krylovii or A. polyrhizum.

\subsection{Biomass measurement}

A total of 30 individuals of S. krylovii and A. polyrhizum (15 individuals of each species) were measured (same 5 individuals of each species were measured before and after the rainfall; Table 1). Each intact plant was cut after the $\mathrm{CO}_{2}$ flux and parameter measurements and separated into aboveground and belowground parts. The separated parts were then dried to a constant weight at $80^{\circ} \mathrm{C}$ for AGB and belowground biomass (BGB) (Table 1).

\subsection{Data processing}

In this study, $\mathrm{CO}_{2}$ uptake by the ecosystem was treated as positive and $\mathrm{CO}_{2}$ emission to the atmosphere was treated as negative. NEP $\left(\mu \mathrm{mol} \mathrm{CO}_{2} /\left(\mathrm{m}^{2} \cdot \mathrm{s}\right)\right.$ ) as $\mathrm{CO}_{2}$ uptake and ER ( $\mu \mathrm{mol}$ $\mathrm{CO}_{2} /\left(\mathrm{m}^{2} \cdot \mathrm{s}\right)$ ) were calculated as the following equation (Hitota et al., 2009):

$$
\mathrm{NEP} \text { or } \mathrm{ER}=d \mathrm{CO}_{2} / d t \times(P /[R(273.15+T)]) V / A,
$$

where $d \mathrm{CO}_{2} / d t$ is the slope of chamber $\mathrm{CO}_{2}$ concentration against time $\left(\mu \mathrm{mol} \mathrm{CO} \mathrm{CO}_{2} /\left(\mathrm{m}^{2} \cdot \mathrm{s}\right)\right) ; P$ is the atmospheric pressure $(\mathrm{kPa}) ; R$ is the gas constant $\left(8.314\left(\mathrm{kPa} \cdot \mathrm{m}^{3}\right) /(\mathrm{K} \cdot \mathrm{mol})\right) ; T$ is the air temperature inside the chamber $\left({ }^{\circ} \mathrm{C}\right) ; V$ is the chamber volume $\left(\mathrm{m}^{3}\right)$; and $A$ is the surface area under the chamber $\left(\mathrm{m}^{2}\right)$. The slope $\left(S=d \mathrm{CO}_{2} / d t\right)$ was obtained by fitting the linear model $(C=S t+b)$ to the sampling data. In the linear model, $C$ is the instantaneous $\mathrm{CO}_{2}$ concentration (ppm) at time $t$ and $\mathrm{b}$ is the intercept.

The GPP $\left(\mu \mathrm{mol} \mathrm{CO} \mathrm{CO}_{2} /\left(\mathrm{m}^{2} \cdot \mathrm{s}\right)\right)$ of the two species was indirectly estimated from NEP and ER using the the following equation:

$$
\mathrm{GPP}=\mathrm{NEP}-\mathrm{ER} \text {. }
$$

The NEP and ER values for estimating GPP were obtained in a series of one-measurement cycle for a target individual plant. The NEP and ER included values of both plants and soils. However, GPP obtained by Equation 2 included only the values of plants, because soil respiration in ER was subtracted from NEP. Thus, GPP obtained using our methods was convenient for comparing the values of productivity of individual plants.

The NEP, ER and GPP are affected by the biomass of individual plants, and GPP is particularly strongly related to AGB (Nakano et al., 2008). Therefore, we defined $\mathrm{GPP}_{\mathrm{AGB}}$ as the GPP 
normalized by the $\mathrm{AGB}$ (i.e., $\mathrm{GPP}_{\mathrm{AGB}}=\mathrm{GPP} / \mathrm{AGB}$ ) and compared the $\mathrm{GPP}_{\mathrm{AGB}}$ between the two species.

Table 1 Measurement period and weight of each measured plant

\begin{tabular}{|c|c|c|c|c|c|c|c|}
\hline \multirow{2}{*}{ Species } & \multicolumn{3}{|c|}{ Measurement period } & \multicolumn{4}{|c|}{ Weight } \\
\hline & $\mathrm{BR}$ & $\mathrm{AR}_{1-2}$ & $\mathrm{AR}_{6}$ & $\operatorname{AGB}(g)$ & BGB (g) & Total (g) & $\mathrm{BGB} / \mathrm{AGB}$ \\
\hline $\mathrm{AP}$ & $\circ$ & & & 0.7606 & 64.4645 & 65.2251 & 84.75 \\
\hline $\mathrm{AP}$ & $\circ$ & & & 1.0083 & 26.0312 & 27.0395 & 25.82 \\
\hline AP & $\circ$ & & & 0.5995 & 59.2651 & 59.8646 & 98.86 \\
\hline $\mathrm{AP}$ & $\circ$ & & & 0.7469 & 45.7020 & 46.4489 & 61.19 \\
\hline AP & $\circ$ & & & 0.7432 & 47.9959 & 48.7391 & 64.58 \\
\hline AP & $\circ$ & $\circ$ & & 0.9098 & 44.3030 & 45.2128 & 48.70 \\
\hline AP & $\circ$ & ० & & 0.5744 & 38.3583 & 38.9327 & 66.78 \\
\hline AP & $\circ$ & $\circ$ & & 0.7081 & 35.5737 & 36.2818 & 50.24 \\
\hline AP & $\circ$ & $\circ$ & & 0.9329 & 20.3247 & 21.2576 & 21.79 \\
\hline $\mathrm{AP}$ & $\circ$ & $\circ$ & & 0.4390 & 16.6598 & 17.0988 & 37.95 \\
\hline $\mathrm{AP}$ & & & $\circ$ & 0.8700 & 43.6151 & 44.4851 & 50.13 \\
\hline AP & & & $\circ$ & 1.2100 & 61.3421 & 62.5521 & 50.70 \\
\hline AP & & & $\circ$ & 0.6400 & 59.0329 & 59.6729 & 92.24 \\
\hline $\mathrm{AP}$ & & & $\circ$ & 1.1000 & 103.1218 & 104.2218 & 93.75 \\
\hline AP & & & ○ & 0.9700 & 46.7165 & 47.6865 & 48.16 \\
\hline SK & $\circ$ & & & 2.5822 & 16.6995 & 19.2817 & 6.47 \\
\hline SK & $\circ$ & & & 2.4994 & 25.4203 & 27.9197 & 10.17 \\
\hline SK & $\circ$ & & & 2.7528 & 49.6921 & 52.4449 & 18.05 \\
\hline SK & $\circ$ & & & 2.4810 & 45.8543 & 48.3353 & 18.48 \\
\hline SK & $\circ$ & & & 2.6536 & 26.1963 & 28.8499 & 9.87 \\
\hline SK & $\circ$ & o & & 3.4241 & 31.1529 & 34.5770 & 9.10 \\
\hline SK & $\circ$ & ० & & 4.4473 & 42.4807 & 46.9280 & 9.55 \\
\hline SK & $\circ$ & o & & 4.3191 & 25.8928 & 30.2119 & 5.99 \\
\hline SK & $\circ$ & ० & & 2.2507 & 24.0583 & 26.3090 & 10.69 \\
\hline SK & $\circ$ & $\circ$ & & 3.7487 & 29.2928 & 33.0415 & 7.81 \\
\hline SK & & & ○ & 1.7500 & 31.3300 & 33.0800 & 17.90 \\
\hline SK & & & ○ & 1.7300 & 23.5444 & 25.2744 & 13.61 \\
\hline SK & & & $\circ$ & 2.6900 & 16.7214 & 19.4114 & 6.22 \\
\hline SK & & & $\circ$ & 2.1300 & 18.7039 & 20.8339 & 8.78 \\
\hline SK & & & ○ & 2.4600 & 54.9600 & 57.4200 & 22.34 \\
\hline
\end{tabular}

Note: AP, Allium polyrhizum; SK, Stipa krylovii; BR, before the rainfall; $\mathrm{AR}_{1-2}$, on the $1^{\text {st }}$ and $2^{\text {nd }} \mathrm{d}$ after the rainfall; $\mathrm{AR}_{6}$, on the $6^{\text {th }} \mathrm{d}$ after the rainfall; AGB, aboveground biomass; BGB, belowground biomass. $\circ$, marked the measurement period of the 30 individuals of S. krylovii and A. polyrhizum before and after the rainfall.

\subsection{Comparison of GPP $_{\mathrm{AGB}}$ between $S$. krylovii and $A$. polyrhizum under different temperature and PAR conditions}

Photosynthesis is strongly influenced by temperature, and in most plants, it occurs within a considerable range of temperature $\left(\mathrm{C}_{3}\right.$ plants: $\left.10^{\circ} \mathrm{C}-35^{\circ} \mathrm{C}\right)$. When temperature goes beyond this range, the photosynthetic system may be damaged (Berry and Björkman, 1980). Thus, we considered $35^{\circ} \mathrm{C}$ as the threshold value of temperature and compared $\mathrm{GPP}_{\mathrm{AGB}}$ below and above $35^{\circ} \mathrm{C}$. Additionally, the daily average and maximum temperatures in July 2015 were $15.2^{\circ} \mathrm{C}-$ $30.4^{\circ} \mathrm{C}$ and $21.1^{\circ} \mathrm{C}-39.3^{\circ} \mathrm{C}$, respectively (data obtained by the WatchDog $2900 \mathrm{ET}$ weather station near the study area).

Saturation curves (Falge et al., 2001) are usually used to describe photosynthetic responses to PAR. However, in this study, these curves were not adequate because of a deficiency of data under high PAR. Therefore, to compare $\mathrm{GPP}_{\mathrm{AGB}}$, we used average values of $\mathrm{GPP}_{\mathrm{AGB}}$ above a 
certain threshold PAR as saturated $\mathrm{GPP}_{\mathrm{AGB}}$ (full and dotted horizontal lines in Figs. 4 and 5). The saturation PAR of $\mathrm{C}_{3}$ plants is $400-500 \mu \mathrm{mol}$ photon $/\left(\mathrm{m}^{2} \cdot \mathrm{s}\right)$ in general, although the saturation PAR varies among plant species (Hodson et al., 2012). Additionally, our results for the relationship between $\mathrm{GPP}_{\mathrm{AGB}}$ and PAR showed the same tendency, and $\mathrm{GPP}_{\mathrm{AGB}}$ saturated under approximately $400 \mu \mathrm{mol}$ photon $/\left(\mathrm{m}^{2} \cdot \mathrm{s}\right)$. Therefore, $400 \mu \mathrm{mol}$ photon $/\left(\mathrm{m}^{2} \cdot \mathrm{s}\right)$ was the threshold value of PAR for comparison of GPP $\mathrm{AGB}_{\text {. Additionally, the GPP }}$ AGB trend line was obtained by the relationship between $\mathrm{GPP}_{\mathrm{AGB}}$ and PAR below $400 \mu \mathrm{mol}$ photon $/\left(\mathrm{m}^{2} \cdot \mathrm{s}\right)$, and the line should go through the origin (full and dotted oblique lines in Figs. 4 and 5). According to our measurements with an LR5000, the average PAR during 05:00-20:00 (LST) from July to August in 2015 was $563 \mu \mathrm{mol}$ photon $/\left(\mathrm{m}^{2} \cdot \mathrm{s}\right)$.
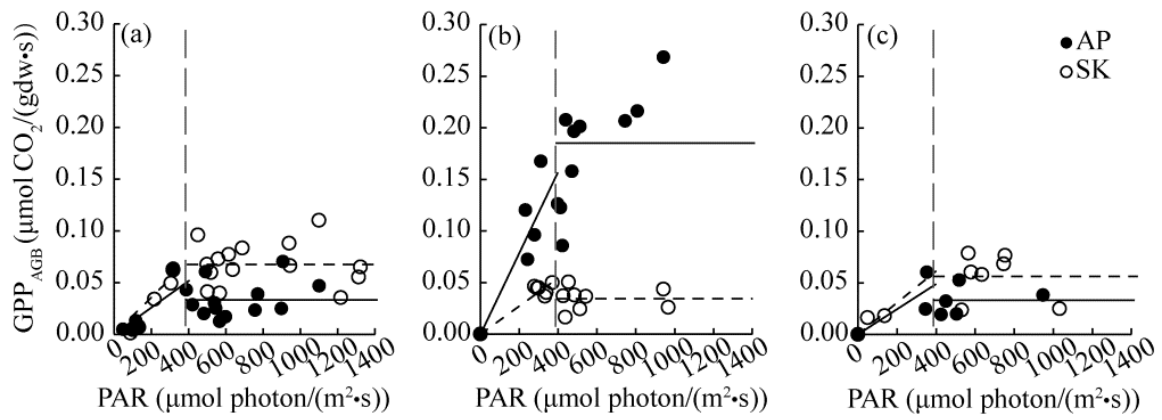

Fig. 4 Relationships between $\operatorname{GPP}_{\mathrm{AGB}}$ and PAR at low temperatures $\left(<35^{\circ} \mathrm{C}\right)$ in different periods in 2015. (a), $\mathrm{BR}$ (before the rainfall); (b), $\mathrm{AR}_{1-2}$ (on the $1^{\text {st }}$ and $2^{\text {nd }} \mathrm{d}$ after the rainfall); (c), $\mathrm{AR}_{6}$ (on the $6^{\text {th }} \mathrm{d}$ after the rainfall). $\mathrm{AP}$, Allium polyrhizum; $\mathrm{SK}$, Stipa krylovii; $\mathrm{GPP}_{\mathrm{AGB}}$, the value of the gross primary productivity normalized by the aboveground biomass; PAR, photosynthetically active radiation. The vertical dotted line represents the light saturation point; the full and dotted oblique lines represent the $\mathrm{GPP}_{\mathrm{AGB}}$ trend line of SK and $\mathrm{AP}$, respectively; and the full and dotted horizontal lines represent the saturated $\mathrm{GPP}_{\mathrm{AGB}}$ values of $\mathrm{SK}$ and $\mathrm{AP}$, respectively.
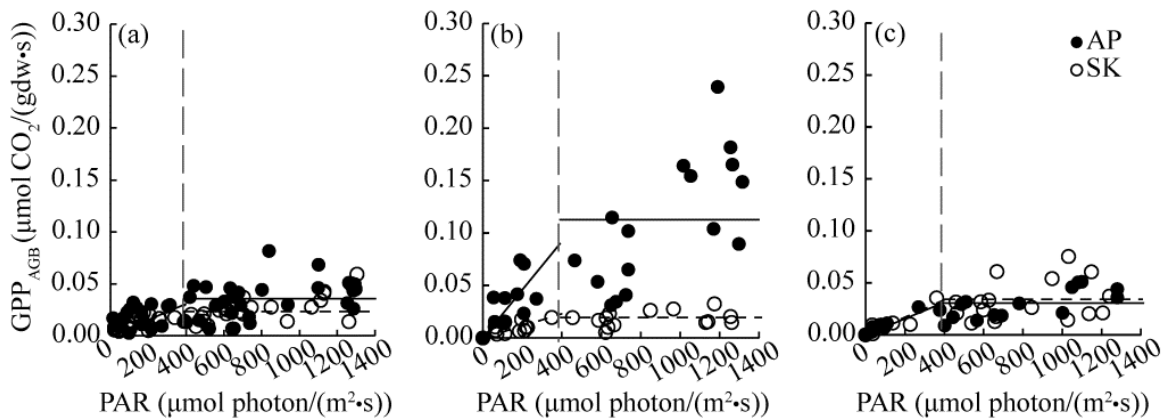

Fig. 5 Relationships between $\mathrm{GPP}_{\mathrm{AGB}}$ and PAR at high temperatures $\left(>35^{\circ} \mathrm{C}\right)$ in different periods $\left(\mathrm{a}, \mathrm{BR} ; \mathrm{b}, \mathrm{AR}_{1-2}\right.$; c, $\mathrm{AR}_{6}$ ) in 2015

\subsection{Statistical analysis}

Statistical analysis was performed with version 22 of IBM SPSS Statistics (IBM corp., Armonk, NY, USA). The saturated $\mathrm{GPP}_{\mathrm{AGB}}$ of the two species among the three periods under different temperature conditions were analyzed by one way analysis of variance and differences among them were analyzed using post hoc Tukey HSD tests, with the level of statistical significance taken as $P<0.05$.

\section{Results}

\subsection{Responses of the saturated GPP $_{\mathrm{AGB}}$ in $S$. krylovii and $A$. polyrhizum to temperature conditions}

Figure 6 shows the saturated $\mathrm{GPP}_{\mathrm{AGB}}$ in relation to temperature for the two species in July 2015 . The saturated $\mathrm{GPP}_{\mathrm{AGB}}$ values of $A$. polyrhizum were very low in the BR (before the rainfall) 
period (Fig. 6a), whereas those in the $\mathrm{AR}_{1-2}$ (on the $1^{\text {st }}$ and $2^{\text {nd }} \mathrm{d}$ after the rainfall) period were obviously high (Fig. $6 \mathrm{~b}$ ). In the $\mathrm{AR}_{6}$ (on the $6^{\text {th }} \mathrm{d}$ after the rainfall) period, the saturated $\mathrm{GPP}_{\mathrm{AGB}}$ values of $A$. polyrhizum returned again to a low level (Fig. 6c). Compared with A. polyrhizum, the

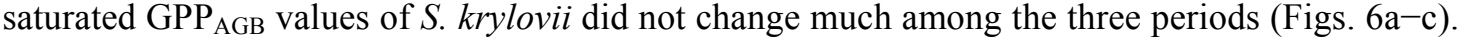
The saturated $\mathrm{GPP}_{\mathrm{AGB}}$ values of $A$. polyrhizum in the $\mathrm{AR}_{1-2}$ period was the highest among the three periods and between the two species. A negative correlation between temperature and the saturated $\mathrm{GPP}_{\mathrm{AGB}}$ of $A$. polyrhizum was observed only in the $\mathrm{AR}_{1-2}$ period $\left(R^{2}=0.23, P<0.05\right.$; Fig. $6 \mathrm{~b}$ ), whereas negative correlations between temperature and the saturated $\mathrm{GPP}_{\mathrm{AGB}}$ of $S$. krylovii appeared in the $\mathrm{BR}\left(R^{2}=0.61, P<0.05\right.$; Fig. $\left.6 \mathrm{a}\right)$ and $\mathrm{AR}_{1-2}\left(R^{2}=0.51, P<0.05\right.$; Fig. $\left.6 \mathrm{~b}\right)$ periods.
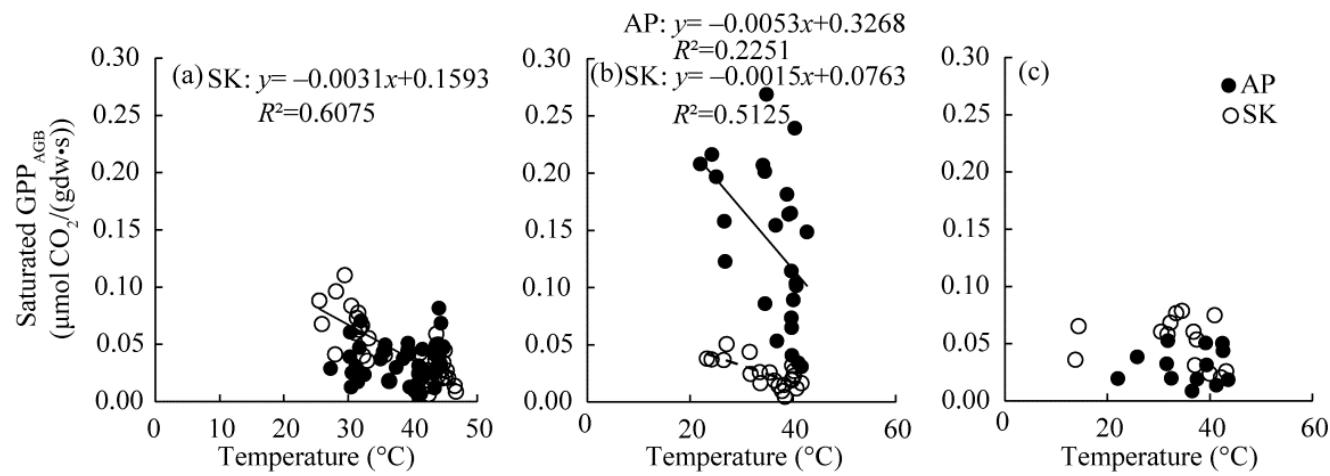

Fig. 6 Relationships between temperature and the saturated $\mathrm{GPP}_{\mathrm{AGB}}$ of $S$. krylovii and A. polyrhizum at PAR higher than $400 \mu \mathrm{mol}$ photon $/\left(\mathrm{m}^{2} \cdot \mathrm{s}\right)$ in different periods $\left(\mathrm{a}, \mathrm{BR} ; \mathrm{b}, \mathrm{AR}_{1-2} ; \mathrm{c}, \mathrm{AR}_{6}\right)$ in 2015 . The fitted line with $R^{2}$ and the linear equation are included only when a significant linear correlation was found between the two variables $(P<0.05)$.

\subsection{Variations of the saturated GPP $_{\mathrm{AGB}}$ in $S$. krylovii and A. polyrhizum at different temperatures before and after the rainfall}

The highest saturated $\mathrm{GPP}_{\mathrm{AGB}}$ value of A polyrhizum was in the $\mathrm{AR}_{1-2}$ period at low temperatures below $35^{\circ} \mathrm{C}(0.185( \pm 0.055) \mu \mathrm{mol} \mathrm{CO} 2 /(\mathrm{gdw} \cdot \mathrm{s})$; Fig. 7a; Table 2$)$, and the second highest $\mathrm{GPP}_{\mathrm{AGB}}$ value was in the $\mathrm{AR}_{1-2}$ period at high temperatures above $35^{\circ} \mathrm{C}\left(0.11( \pm 0.061) \mu \mathrm{mol} \mathrm{CO}_{2} /(\mathrm{gdw} \cdot \mathrm{s})\right.$; Fig. 7b; Table 2). Range of the saturated $\mathrm{GPP}_{\mathrm{AGB}}$ values of $A$. polyrhizum during the measurement period was $0.011-0.089 \mu \mathrm{mol} \mathrm{CO} 2 /(\mathrm{gdw} \cdot \mathrm{s})$ except for in the $\mathrm{AR}_{1-2}$ period. These results showed that the saturated GPP ${ }_{\mathrm{AGB}}$ values of $A$. polyrhizum increased remarkably immediately after the rainfall but decreased to a low level soon in the $\mathrm{AR}_{6}$ period. By contrast, no significant differences in the saturated $\mathrm{GPP}_{\mathrm{AGB}}$ values of $S$. krylovii were observed before and after the rainfall (Fig. 7). The saturated $\mathrm{GPP}_{\mathrm{AGB}}$ values of $S$. krylovii were significantly lower at high temperatures $(0.026( \pm 0.013) \mu \mathrm{mol} \mathrm{CO} 2 /(\mathrm{gdw} \cdot \mathrm{s}))$ than at low temperatures $(0.068( \pm 0.021) \mu \mathrm{mol}$ $\left.\mathrm{CO}_{2} /(\mathrm{gdw} \cdot \mathrm{s})\right)$ in the BR period. However, no significant difference of the saturated GPP ${ }_{\mathrm{AGB}}$ values was observed in A. polyrhizum between high and low temperatures in the BR period.
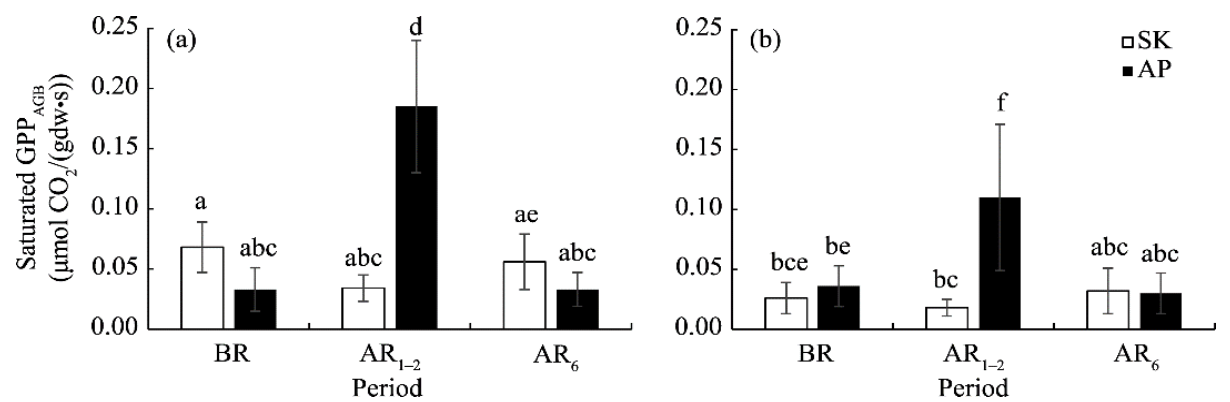

Fig. 7 Saturated $\mathrm{GPP}_{\mathrm{AGB}}$ of $S$. krylovii and A. polyrhizum at PAR higher than $400 \mu \mathrm{mol}$ photon $/\left(\mathrm{m}^{2} \cdot \mathrm{s}\right)$ under different temperature conditions in different periods (BR, $\mathrm{AR}_{1-2}$ and $\left.\mathrm{AR}_{6}\right)$. (a), the temperature was below $35^{\circ} \mathrm{C}$; (b), the temperature was above $35^{\circ} \mathrm{C}$. Bars represent standard errors. Different lowercase letters indicate significant differences in the saturated $\mathrm{GPP}_{\mathrm{AGB}}$ values of $S$. krylovii or A. polyrhizum among different periods at $P<0.05$ level. 
Table 2 Initial slope of the $\mathrm{GPP}_{\mathrm{AGB}}$ to PAR at PAR lower than $400 \mu \mathrm{mol}$ photon $/\left(\mathrm{m}^{2} \cdot \mathrm{s}\right)$ and the saturated $\mathrm{GPP}_{\mathrm{AGB}}$ values of $S$. krylovii and $A$. polyrhizum at PAR higher than $400 \mu \mathrm{mol}$ photon $/\left(\mathrm{m}^{2} \cdot \mathrm{s}\right)$ under different temperature conditions in different periods

\begin{tabular}{|c|c|c|c|c|c|}
\hline \multirow{2}{*}{$\begin{array}{c}\text { Temperature } \\
\text { condition }\end{array}$} & \multirow[b]{2}{*}{ Period } & \multicolumn{2}{|c|}{ S. krylovii } & \multicolumn{2}{|c|}{ A. polyrhizum } \\
\hline & & Initial slope & $\begin{array}{c}\text { Saturated } \mathrm{GPP}_{\mathrm{AGB}} \\
\left(\mu \mathrm{mol} \mathrm{CO}_{2} /(\mathrm{gdw} \cdot \mathrm{s})\right)\end{array}$ & Initial slope & $\begin{array}{c}\text { Saturated } \mathrm{GPP}_{\mathrm{AGB}} \\
\left(\mu \mathrm{mol} \mathrm{CO} \mathrm{CO}_{2} /(\mathrm{gdw} \cdot \mathrm{s})\right)\end{array}$ \\
\hline \multirow{3}{*}{ Below $35^{\circ} \mathrm{C}$} & $\mathrm{BR}$ & $1.78 \times 10^{-4}$ & $0.068 \pm 0.021$ & $1.29 \times 10^{-4}$ & $0.033 \pm 0.018$ \\
\hline & $\mathrm{AR}_{1-2}$ & $1.36 \times 10^{-4}$ & $0.034 \pm 0.011$ & $3.93 \times 10^{-4}$ & $0.185 \pm 0.055$ \\
\hline & $\mathrm{AR}_{6}$ & $1.53 \times 10^{-4}$ & $0.056 \pm 0.023$ & $1.22 \times 10^{-4}$ & $0.033 \pm 0.014$ \\
\hline \multirow{3}{*}{ Above $35^{\circ} \mathrm{C}$} & $\mathrm{BR}$ & $7.45 \times 10^{-5}$ & $0.026 \pm 0.013$ & $7.69 \times 10^{-5}$ & $0.036 \pm 0.017$ \\
\hline & $\mathrm{AR}_{1-2}$ & $5.76 \times 10^{-5}$ & $0.018 \pm 0.007$ & $2.30 \times 10^{-4}$ & $0.110 \pm 0.061$ \\
\hline & $\mathrm{AR}_{6}$ & $8.54 \times 10^{-5}$ & $0.032 \pm 0.019$ & $7.88 \times 10^{-5}$ & $0.030 \pm 0.017$ \\
\hline
\end{tabular}

Note: $\mathrm{BR}$, before the rainfall; $\mathrm{AR}_{1-2}$, on the $1^{\text {st }}$ and $2^{\text {nd }} \mathrm{d}$ after the rainfall; $\mathrm{AR}_{6}$, on the $6^{\text {th }} \mathrm{d}$ after the rainfall; $\mathrm{GPP}_{\mathrm{AGB}}$, the value of the gross primary productivity normalized by the aboveground biomass. Mean $\pm \mathrm{SD}$.

\section{Discussion}

\subsection{Variations of the $\mathrm{GPP}_{\mathrm{AGB}}$ in $S$. krylovii and $A$. polyrhizum at different temperatures before and after the rainfall}

In arid and semi-arid areas, rainfall is a key variable that affects the growth and photosynthesis of plants. The present study showed that $A$. polyrhizum demonstrated increased saturated $\mathrm{GPP}_{\mathrm{AGB}}$ by water supply soon after the rainfall in the $\mathrm{AR}_{1-2}$ period (Fig. 7). Additionally, the GPP $\mathrm{AGB}$ values at low temperatures below $35^{\circ} \mathrm{C}$ were significantly higher than those at high temperatures (above $35^{\circ} \mathrm{C}$ ). By contrast, the saturated $\mathrm{GPP}_{\mathrm{AGB}}$ values of $S$. krylovii were also significantly higher at low temperatures in the $\mathrm{BR}$ period. However, the values in the $\mathrm{AR}_{1-2}$ period did not show obvious changes but maintained a steady state. Thus, the responses of the saturated $\mathrm{GPP}_{\mathrm{AGB}}$ to the temporal rainfall differed between the two species and strongly negative influenced by temperature.

The saturated $\mathrm{GPP}_{\mathrm{AGB}}$ values of $A$. polyrhizum on the $1^{\text {st }}$ and $2^{\text {nd }} \mathrm{d}$ after the rainfall (mean of $0.185( \pm 0.055) \mu \mathrm{mol} \mathrm{CO} 2 /(\mathrm{gdw} \cdot \mathrm{s}))$ were relatively high compared with the saturated $\mathrm{GPP}_{\mathrm{AGB}}$ values of a previous study in a semi-arid grassland of Mongolia $\left(0.094-0.156 \mu \mathrm{mol} \mathrm{CO}_{2} /(\mathrm{gdw} \cdot \mathrm{s})\right)$ in July (Nakano et al., 2008). The environmental conditions of the two study sites are relatively similar. The mean temperature and precipitation in July at our study site were $22.7^{\circ} \mathrm{C}$ and $9.1 \mathrm{~mm}$, respectively, and they were $17.8^{\circ} \mathrm{C}-22.5^{\circ} \mathrm{C}$ and $8.4-21.6 \mathrm{~mm}$, respectively, at the study site in the

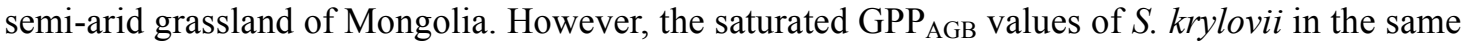
period were comparatively lower $\left(0.034( \pm 0.011) \mu \mathrm{molCO}_{2} /(\mathrm{gdw} \cdot \mathrm{s})\right)$ in our study than those in

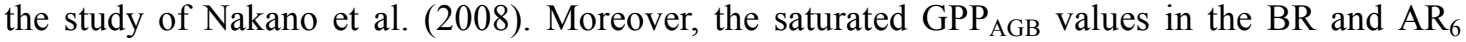
periods of the two species in this study were slightly lower than those presented in the study of Nakano et al. (2008). Thus, the saturated $\mathrm{GPP}_{\mathrm{AGB}}$ values of each species are likely to have extremes that are high or low, and $A$. polyrhizum had a higher saturated GPP $_{\mathrm{AGB}}$ value than $S$. krylovii after the rainfall.

Several studies analyzed the effects of temporal rainfall on grasslands. Li et al. (2013) indicated that the $\mathrm{CO}_{2}$ flux and productivity increased with increasing amounts of rainfall. However, a lower limit threshold of rainfall amount occurs for a plant's response. Hao et al. (2010) suggested that the ecologically effective rainfall size for a response in productivity was 5.0 $\mathrm{mm}$ in the grasslands of Inner Mongolia. Thus, the plants would produce no ecological effect from the rainfall when the rainfall size is below $5.0 \mathrm{~mm}$. According to these reports, the rainfall in 25 July $2015(9.1 \mathrm{~mm})$ in our study could be considered as an ecologically effective rainfall. Furthermore, Huxman et al. (2004) reported that the durations of the rainfall effect on productivities were related to the rainfall amount in the deserts of North America. According to their model, the ecological effects of a $10.0-\mathrm{mm}$ rainfall will last for approximately $2 \mathrm{~d}$. In our study, the saturated GPP ${ }_{\mathrm{AGB}}$ values of $A$. polyrhizum in the $\mathrm{AR}_{1-2}$ period were considerably higher than those in the BR period. However, the saturated $\mathrm{GPP}_{\mathrm{AGB}}$ values of $A$. polyrhizum in the $\mathrm{AR}_{6}$ 
period had returned to the level in the BR period. The rainfall effect apparently disappeared more than 3 to $5 \mathrm{~d}$ after the rainfall. By contrast, the rainfall amount was insufficient for $S$. krylovii to show an effective response in the GPP $\mathrm{AGB}_{\text {. }}$

\subsection{Possible reasons for the different responses of the two species to the temporal rainfall}

In several studies, the productivity increases with an effective water supply in the grasslands. Thomey et al. (2014) used rainout shelters to alter the amount and frequency of rainfall and compared the $\mathrm{A}_{\text {net }}$ (leaf gas exchange) of the dominant $\mathrm{C}_{4}$ grasses Bouteloua eriopoda and Bouteloua gracilis in a grassland in New Mexico, USA. The $\mathrm{A}_{\text {net }}$ of $B$. gracilis and B. eriopoda increased by 2.2- and 1.8-fold after a 10.0-mm rainfall, respectively. Xiong et al. (2017) conducted a study in a semi-arid grassland in Shaanxi Province, China, in which the community was dominated by Bothriochloa ischaemum $\left(\mathrm{C}_{4}\right.$ grass) and Lespedeza davurica $\left(\mathrm{C}_{3}\right.$ subshrub). The peak net photosynthetic rates of B. ischaemum and L. davurica increased by 1.5 - and 1.2 -fold after a 10.0-mm rainfall in June, respectively. Some studies also compare area-based GPP (not based on biomass). Chen et al. (2009) analyzed the GPP with water applied at four artificial levels $(5,10,25$ and $75 \mathrm{~mm})$ using a chamber method in a grassland of Inner Mongolia with the dominant species of S. krylovii. The GPP increased by 1.2-, 1.6-, 2.2- and 2.4-fold soon after the 5.0, 10.0, 25.0 and $75.0 \mathrm{~mm}$ water supplies, respectively. Guo et al. (2016) examined the effects of individual rainfall and $\mathrm{N}$ addition on GPP using a chamber method in a grassland of Inner Mongolia that included the species of S. krylovii. The GPP in the control treatment (no N addition) increased by 1.1-, 1.3-, 1.7- and 2.6-fold within $1 \mathrm{~d}$ after 4.7, 7.7, 11.0 and $19.6 \mathrm{~mm}$ rainfalls, respectively. In our study, the saturated $\mathrm{GPP}_{\mathrm{AGB}}$ values of $A$. polyrhizum increased by 5.6-fold and those of $S$. krylovii decreased by 0.5 -fold at low temperatures below $35^{\circ} \mathrm{C}$ in the $\mathrm{AR}_{1-2}$ period compared to the BR period. Comparing the increasing rate of the GPP values in our study with those in the studies of Chen et al. (2009) and Guo et al. (2016), the increasing rate of A. polyrhizum was higher and that of $S$. krylovii was lower than those in the two studies, which suggests that great variations occur in physiological responses to the temporal rainfall among species in temperate grassland communities.

The rapid responses of $A$. polyrhizum to the temporal rainfall were likely because of its water use strategy. Ivanov et al. (2004) reported that A. polyrhizum is characterized by the water storage in photosynthesizing cells and by the high photosynthetic rate under conditions of sufficient water supply. This result is consistent with our results that the saturated $\mathrm{GPP}_{\mathrm{AGB}}$ values of $A$. polyrhizum increased soon after the rainfall. Additionally, A. polyrhizum has linear and cylindrical leaves, which are characterized by a high water content (Ivanov et al., 2004). The physiological and structural features of $A$. polyrhizum leaves allow them to increase the biomass and size of the photosynthetic apparatus quickly under conditions of sufficient water supply. We could also explain the difference between A. polyrhizum and S. krylovii based on characters of the root system. A. polyrhizum is a type of shallow-root system species, and its roots are concentrated in the surface soil layer of 3-12 cm depth (Chen et al., 2001). In contrast to A. polyrhizum, S. krylovii has a deeper root system, and its roots are concentrated in the deeper soil layer (depth of $25 \mathrm{~cm}$, even to a depth of $50 \mathrm{~cm}$ ) (Chen et al., 2001). Deep-rooted plants often experience less water stress during dry periods than shallow-rooted plants because of their ability to draw on deep water reserves that are available for a longer time after a rainfall, but may also respond more slowly and with less sensitivity to the current rainfall (Schwinning et al., 2002). According to the results of Huxman et al. (2004), for shallow-rooted species, photosynthesis recovers rapidly after the rainfall. Moreover, A. polyrhizum holds and retains atmospheric moisture because of the powerful and well-developed roots (Gunin et al., 2015). In our study, the mass of the belowground part exceeded that of the aboveground part, and the ratio of BGB/AGB in $A$. polyrhizum $59.7( \pm 23.1)$ was significantly higher than that in $S$. krylovii 11.7 ( \pm 5.0$)$ (U-test, $P<0.05)$. Our results showed that the relatively shallow-rooted $A$. polyrhizum responded more rapidly to rainfall than the relatively deep-rooted $S$. krylovii. Therefore, the contrasting patterns between the responses of the two species to the temporal rainfall suggest that such differences are related to differences in their species-specific survival strategies. 
Drought induced by climate change increases the degradation of grasslands in Inner Mongolia, and therefore, adaptability to drought is essential for grassland species. Previous studies demonstrated the strong adaptability of A. polyrhizum (Gunin et al., 2015) and S. krylovii (Chen et al., 2013) to drought stress. Nevertheless, our results showed that the two species have different physiological responses to the temporal rainfall. Additionally, Sun et al. (2011) suggested that the stress tolerance of $A$. cristatum against drought is higher than that of $S$. krylovii. Thus, multiple comparisons among the species in the grasslands of Inner Mongolia are necessary for a comprehensive understanding of the grassland community.

Our results showed that the interactive effect of rainfall and temperature and the effect of temporal rainfall on GPP help us understand the adaptability of the two species to drought. However, our study was conducted only in a dry year. To understand the adaptability to drought more accurately, further long-term research that includes wet years is necessary.

\section{Conclusions}

In this study, we compared the responses of the saturated $\mathrm{GPP}_{\mathrm{AGB}}$ between two representative species (S. krylovii and A. polyrhizum) to a temporal rainfall in a dry year in a temperate grassland of Inner Mongolia, China. We found that the saturated GPP $_{\mathrm{AGB}}$ values of both the two species were strongly negative effected by temperature. Additionally, the saturated GPP AGB values of $A$. polyrhizum responded rapidly to the temporal rainfall, whereas the values of $S$. krylovii did not show obvious changes but remained stable after the rainfall. Such differences are apparently related to the difference in their species-specific survival strategies against drought. The different responses of GPP may help explain the coexistence of the two representative species in the grasslands of Inner Mongolia.

\section{Acknowledgements}

This research was jointly supported by the National Natural Science Foundation of China $(31470504,31670455)$, the Grant-in-Aid for Scientific Research by the Japan Society for the Promotion of Science (grant 23405001) and the National Key Research and Development Program of China (2016YFC0500908). We thank Mr. MA Xuping and Mr. ZHANG Xiulong for their kind assistance with field work and valuable suggestions.

\section{References}

Adams J M, Faure H, Faure-Denard L, et al. 1990. Increases in terrestrial carbon storage from the last glacial maximum to the present. Nature, 348: 711-714.

Berry J A, Björkman O. 1980. Photosynthetic response and adaptation to temperature in higher plants. Annual Review of Plant Physiology, 31: 491-543.

Chen L P, Zhao N X, Zhang L H, et al. 2013. Responses of two dominant plant species to drought stress and defoliation in the Inner Mongolia Steppe of China. Plant Ecology, 214(2): 221-229.

Chen S H, Zhang H, Wang L Q, et al. 2001. Grassland Plant Roots in Northern China. Jilin: Jilin University Press, 81-83, 470471. (in Chinese)

Chen S P, Lin G H, Huang J H, et al. 2009. Dependence of carbon sequestration on the differential responses of ecosystem photosynthesis and respiration to rain pulses in a semiarid steppe. Global Change Biology, 15(10): 2450-2461.

Cheng Y X, Kamijo T, Tsubo M, et al. 2013. Phytosociology of Hulunbeier grassland vegetation in Inner Mongolia, China. Phytocoenologia, 43(1-2): 41-51.

Ciais P, Reichstein M, Viovy N, et al. 2005. Europe-wide reduction in primary productivity caused by the heat and drought in 2003. Nature, 437: 529-533.

Falge E, Baldocchi D, Olson R, et al. 2001. Gap filling strategies for defensible annual sums of net ecosystem exchange. Agricultural and Forest Meteorology, 107(1): 43-69.

Gao Q, Reynolds J F. 2003. Historical shrub-grass transitions in the northern Chihuahuan Desert: Modeling the effects of shifting rainfall seasonality and event size over a landscape gradient. Global Change Biology, 9(10): 1475-1493.

Granier A, Reichstein M, Bréda N, et al. 2007. Evidence for soil water control on carbon and water dynamics in European forests during the extremely dry year: 2003. Agricultural and Forest Meteorology, 143(1-2): 123-145. 
Gunin P D, Bazha S N, Danzhalova E V, et al. 2015. Regional features of desertification processes of ecosystems on the border of the Baikal Basin and Central Asian internal drainage basin. Arid Ecosystems, 5(3): 117-133.

Guo Q, Hu Z M, Li S G, et al. 2012. Spatial variations in aboveground net primary productivity along a climate gradient in Eurasian temperate grassland: Effects of mean annual precipitation and its seasonal distribution. Global Change Biology, 18(12): 3624-3631.

Guo Q, Hu Z M, Li S G, et al. 2016. Exogenous N addition enhances the responses of gross primary productivity to individual precipitation events in a temperate grassland. Scientific Reports, 6: 26901.

Han D M, Wang G Q, Xue B L, et al. 2018. Evaluation of semiarid grassland degradation in North China from multiple perspectives. Ecological Engineering, 112: 41-50.

Hao Y B, Wang Y F, Mei X R. 2010. The response of ecosystem $\mathrm{CO}_{2}$ exchange to small precipitation pulses over a temperate steppe. Plant Ecology, 209(2): 335-347.

Harpole W S, Potts D L, Suding K N. 2007. Ecosystem responses to water and nitrogen amendment in a California grassland. Global Change Biology, 13(11): 2341-2348.

Hirota M, Tang Y H, Hu Q W, et al. 2006. Carbon dioxide dynamics and controls in a deep-water wetland on the Qinghai-Tibetan Plateau. Ecosystems, 9(4): 673-688.

Hirota M, Zhang P C, Gu S, et al. 2009. Altitudinal variation of ecosystem $\mathrm{CO}_{2}$ fluxes in an alpine grassland from 3600 to 4200 m. Journal of Plant Ecology, 2(4): 197-205.

Hirota M, Zhang P C, Gu S, et al. 2010. Small-scale variation in ecosystem $\mathrm{CO}_{2}$ fluxes in an alpine meadow depends on plant biomass and species richness. Journal of Plant Research, 123(4): 531-541.

Hodson M J, Bryant J A. 2012. Functional Biology of Plants. Chichester: John Wiley \& Sons, Ltd., 166-188.

Hooper D U, Johnson L. 1999. Nitrogen limitation in dryland ecosystems: Responses to geographical and temporal variation in precipitation. Biogeochemistry, 46(1-3): 247-293.

Hunt J E, Kelliher F M, Mcseveny T M, et al. 2004. Long-term carbon exchange in a sparse, seasonally dry tussock grassland. Global Change Biology, 10(10): 1785-1800.

Huxman T E, Snyder K A, Tissue D, et al. 2004. Precipitation pulses and carbon fluxes in semiarid and arid ecosystems. Oecologia, 141(2): 254-268.

Ivanov L A, Ivanova L A, Ronzhina D A, et al. 2004. Structural and functional grounds for Ephedra sinica expansion in Mongolian steppe ecosystems. Russian Journal of Plant Physiology, 51(4): 469-475.

Kawada K, Wuyunna, Nakamura T. 2011. Land degradation of abandoned croplands in the Xilingol steppe region, Inner Mongolia, China. Japanese Society of Grassland Science, 57(1): 58-64.

Knapp A K, Smith M D. 2001. Variation among biomes in temporal dynamics of aboveground primary production. Science, 291(5503): 481-484.

Li F, Zhao W Z, Liu H. 2013. The response of aboveground net primary productivity of desert vegetation to rainfall pulse in the temperate desert region of Northwest China. PLoS ONE, 8(9): e73003.

Li S G, Asanuma J, Eugster W, et al. 2005. Net ecosystem carbon dioxide exchange over grazed steppe in Central Mongolia. Global Change Biology, 11(11): 1941-1955.

Li Z L, Zhang Y T, Yu D F, et al. 2014. The influence of precipitation regimes and elevated $\mathrm{CO}_{2}$ on photosynthesis and biomass accumulation and partitioning in seedlings of the rhizomatous perennial grass Leymus chinensis. PloS ONE, 9(8): e103633.

Lin L, Wuyunna, Tamura K, et al. 2013. Variation of soil physicochemical and microbial properties in degraded steppes in Hulunbeir of China. Chinese Journal of Applied Ecology, 24(12): 3407-3414. (in Chinese)

Liu Y S, Pan Q M, Zhang S X, et al. 2012. Intra-seasonal precipitation amount and pattern differentially affect primary production of two dominant species of Inner Mongolia grassland. Acta Oecologica, 44: 2-10.

Ma S Y, Baldocchi D D, Xu L K, et al. 2007. Inter-annual variability in carbon dioxide exchange of an oak/grass savanna and open grassland in California. Agricultural and Forest Meteorology, 147(3-4): 157-171.

Nakano T, Nemoto M, Shinoda M. 2008. Environmental controls on photosynthetic production and ecosystem respiration in semi-arid grasslands of Mongolia. Agricultural and Forest Meteorology, 148(10): 1456-1466.

Novick K A, Stoy P C, Katul G G, et al. 2004. Carbon dioxide and water vapor exchange in a warm temperate grassland. Oecologia, 138(2): 259-274.

Pereira J S, Chaves M M, Caldeira M C, et al. 2006. Water availability and productivity. In: Morison J I, Morecroft M D. Plant Growth and Climate Change. London: Blackwell Publishers, 118-145.

Reynolds S, Batello C, Baas S, et al. 2005. Grassland and forage to improve livelihoods and reduce poverty. In: McGilloway D A. Grassland: A Global Resource. Wageningen: Wageningen Academic Publishers, 323-338.

Robertson T R, Bell C W, Zak J C, et al. 2009. Precipitation timing and magnitude differentially affect aboveground annual net 
primary productivity in three perennial species in a Chihuahuan Desert grassland. New Phytologist, 181: 230-242.

Sala O E, Parton W J, Joyce L A, et al. 1988. Primary production of the central grassland region of the United States. Ecology, 69(1): 40-45.

Schwinning S, Davis K, Richardson L, et al. 2002. Deuterium enriched irrigation indicates different forms of rain use in shrub/grass species of the Colorado Plateau. Oecologia, 130(3): 345-355.

Shi Z, Thomey M L, Mowll W, et al. 2014. Differential effects of extreme drought on production and respiration: Synthesis and modeling analysis. Biogeosciences, 11(3): 621-633.

Sun J, Liu M, Li S G, et al. 2011. Survival strategy of Stipa krylovii and Agropyron cristatum in typical steppe of Inner Mongolia. Acta Ecologica Sinica, 31(8): 2148-2158. (in Chinese)

Sun J, Du W P. 2017. Effects of precipitation and temperature on net primary productivity and precipitation use efficiency across China's grasslands. GIScience and Remote Sensing, 54(6): 881-897.

Thomey M L, Collins S L, Friggens M T, et al. 2014. Effects of monsoon precipitation variability on the physiological response of two dominant $\mathrm{C}_{4}$ grasses across a semiarid ecotone. Oecologia, 176(3): 751-762.

Wang T, Xue X, Zhou L, et al. 2015. Combating aeolian desertification in northern China. Land Degradation and Development, 26(2): 118-132.

Wuyunna, Zhang F J, Ran C Q. 2009. Analysis of climatic change in Basin of Kherlen River of Mongolia Plateau for the past 50 years. Journal of Dalian Minzu University, 11(3): 193-195. (in Chinese)

Xiong P F, Shu J L, Zhang H, et al. 2017. Small rainfall pulses affected leaf photosynthesis rather than biomass production of dominant species in semiarid grassland community on Loess Plateau of China. Functional Plant Biology, 44(12): 1229-1242.

$\mathrm{Xu} \mathrm{L} \mathrm{K,} \mathrm{Baldocchi} \mathrm{D} \mathrm{D.} \mathrm{2004.} \mathrm{Seasonal} \mathrm{variation} \mathrm{in} \mathrm{carbon} \mathrm{dioxide} \mathrm{exchange} \mathrm{over} \mathrm{a} \mathrm{Mediterranean} \mathrm{annual} \mathrm{grassland} \mathrm{in}$ California. Agricultural and Forest Meteorology, 123(1-2): 79-96.

Zhang P C, Hirota M, Shen $\mathrm{H} \mathrm{H}$, et al. 2009. Characterization of $\mathrm{CO}_{2}$ flux in three Kobresia meadows differing in dominant species. Journal of Plant Ecology, 2(4): 187-196.

Zhao N X, Gao Y B, Wang J L, et al. 2006. Genetic diversity and population differentiation of the dominant species Stipa krylovii in the Inner Mongolia steppe. Biochemical Genetics, 44(11-12): 504-517. 